\title{
MEMORY TRANSMISSION, SURVIVAL AND MULTICULTURALISM IN CONTEMPORARY
}

CANADIAN LITERATURE

\author{
Adina Balint \\ The University of Winnipeg \\ Winnipeg, Canadá
}

\begin{abstract}
In 2014, the Quebecois writer Catherine Mavrikakis published Diamanda Galas, a tribute to the American artist performer of Greek origin, Diamanda Galas - at the Montreal Publishing House, Héliotrope, inaugurating a new collection, "Guerrières et Gorgones" (Warriors and Gorgons). At the same time and in the same collection, Martine Delvaux published a tribute to the American photographer Nan Goldin, in an eponymous essay. "What survives from/through artists who are prophets of the contemporary?”, inquires Mavrikakis. Acting on the tragedy of history and transgressing it, how can literature and art play with experiences of memory transmission and "survival" without necessarily working "to fix" them? What is at the heart of this link between history and creativity, reaffirmed by Georges Didi-Huberman in Survivance des lucioles? Through reflections on transcultural transference, multiculturalism and the power of women to transgress traumatic experiences, this article explores the question of memory transmission in two contemporary narratives on art and the AIDS period of the 1980s.
\end{abstract}

Keywords: memory transmission, survival, multiculturalism, contemporary Canadian Literature, literature and art.

\section{Résumé}

En 2014 , l'écrivaine québécoise Catherine Mavrikakis publie Diamanda Galas, un récit hommage à l'artiste musicienne américaine d'origine grecque, Diamanda Galas, aux éditions Héliotrope à Montréal, inaugurant une nouvelle collection intitulée "Guerrières et Gorgones" À la même époque et dans la même collection, une autre écrivaine québécoise, Martine Delvaux, publie un récit hommage à la photographe américaine contemporaine Nan Goldin. "Quel culte peut-on porter aux artistes prophètes $\mathrm{du}$ contemporain ?", interroge Mavrikakis. En puisant dans le tragique de l'époque

\section{Resumo}

Em 2014, a escritora quebequense Catherine Mavrikakis publica Diamanda Galas, uma narrativa em homenagem à artista e musicista americana de origim grega, Diamanda Galas, pela editora Héliotrope de Montréal, inaugurando uma nova coleção intitulada "Guerrières et Gorgones”. Na mesma época e na mesma coleção, outra escritora quebequense, Martine Delvaux, publica uma narrativa em homenagem à fotógrafa americana contemporânea Nan Goldin. "Que culto podemos reservar aos artistas profetas da contemporaneidade?", interroga-se Mavrikakis. Insperando-se 
du SIDA des années 1980 pour tenter de le transgresser, la littérature peut-elle transmettre des expériences traumatiques et de "survivance" sans se donner pour but de les "régler"? Et quel lien entre histoire, créativité et mémoire, tel qu'évoqué par Georges Didi-Huberman dans Survivance des lucioles? Par des réflexions sur le transculturel, le multiculturalisme et la force des femmes à passer au-delà des traumas personnels et collectifs, nous explorons la question de la transmission de la mémoire dans la littérature contemporaine canadienne en nous attachant à deux récits publiés récemment au Québec.

Mots-clés: Transmission de la mémoire, survivance et multiculturalisme dans la littérature canadienne contemporaine. no trágico da época da AIDS dos anos 1980 para tentar transgredi-lo, a literatura poderá transmitir experiências traumáticas e de "sobrevivência" sem ter a finalidade "regulá-las"? E qual o vínculo entre história, criatividade e memória, tal como foi evocado por Georges DidiHuberman em Survivance des lucioles? Através das reflexões sobre o transcultural, o multiculturalismo e a força das mulheres em passar além dos traumas pessoais e coletivos, exploramos a questão da transmissão da memória na literatura contemporânea canadense tendo por base essas duas narrativas recentemente publicadas no Quebec.

Palavras-chave: transmissão memorial, sobrevivência, multiculturalismo, literatura canadense contemporânea, literatura e arte.

\section{Introduction}

Is there a special way in which Canadians are committed to the idea of memory transmission and "survival" of the past? That such a commitment has shaped Canadian literature is one of the basic themes of Margaret Atwood's first critical work, Survival, published in 1972. Survival is simultaneously a book of criticism, a manifesto, and a collection of personal and subversive remarks that received a startling critical acclaim in the 1970s. Atwood begins by asking: "What have been the central preoccupations of our poetry and fiction?". Her answer is: "survival and victims". The word "survival" becomes thus essential as it represents, according to the author, "the central symbol for Canada - and it is based on numerous instances of its occurrence in both English and French Canadian literature" (ATWOOD, 1972: 32) - in the same way as the Frontier is "possibly the symbol for America" (ATWOOD, 1972: 31), and "the corresponding symbol for England is perhaps The Island"(ibidem). Through Survival, Atwood presents and supports - with interesting examples from the works of John Newlore, Al Purdy, D.G. Jones - the theory that Canadian literature is misshapen by a state of mind directly linked to the colonial paradigms. She seriously states: "our literature reflects an attitude to life that aims no higher than survival" (ATWOOD, 1972: 9).

Thus what values are typically Canadian? If current social theory is valid and such values are "constructed" by the societies we inhabit, how do values 
define Canadian literature or literatures? How are they imbedded, encoded or expressed in Canadian culture or cultures?

Almost forty-five years have passed since the publication of Survival by Margaret Atwood. Today, a question goes without saying: How can we speak about contemporary Canadian literature - Anglophone or Francophone? Along these lines, it is paradoxical to notice that in 2010, Canadian Literature - a bilingual quarterly journal that includes an extensive list of reviews on Canadian books of all genres - records the same feeling of skepticism towards Canadian literature like in the 1970s:

If you type CanLit or Canadian literature into Google, you get our home page [Canadian Literature journal]. And it seems appropriate to announce at this point that there were 24,000 hits in the last 30 days on the back issues that have been free online there since the end of October 2009. [...] We cannot bask in this statistic, however. Here is a response to our survey asking about how readers use these free PDFs: 'I look around in vain for interesting content', What to make of this reply? [...]Here is another comment on what would be welcome on our website: 'Interesting, NEW content by not yet established writers. The same old Canadian writers are BORING and so are the new that get through'. So Canadian Literature (the journal), Canadian literature (the literature), and CanLit (either or both) are boring. ${ }^{1}$

These selections are arbitrary, inter-related and obviously generic. Behind them lies one basic assumption: the way people in a particular society relate to narratives and literature - or rather invent, then collude in, a collective imaginary about literature - can be located in patterns of intellectual and cultural expression. Such patterns are demonstrated through the ways in which culture related subjects are treated or expressed. What do Canadians choose to write about? What issues intrigue them? What point of view is taken? What atmosphere is created? What is considered to be "boring"? What assumptions are made? More importantly - regarding the characteristics of a Canadian stance - further questions ask to be raised: How can a sense of Canadian identity coexist with internationalism? And how can regionalism find a place in this combination? Holding in suspense one, two or more sets of values, we can assume that Canadians are comfortable with sociologist's John Porter's concept of "vertical mosaic", as it acknowledges a nation composed of a variety of ethnic groups, and "a national predisposition not to interfere with the customs, beliefs and rights of those different from oneself". ${ }^{2}$

\footnotetext{
${ }^{1}$ Margery Fee,"Beyond Boomer Nationalism”, CanLit, no. 206, autumn 2010, p. 6-11. URL: https://canlit.ca/article/beyond-boomer-nationalism/ (browsed on April 12, 2016).

${ }^{2}$ Elspeth Cameron (ed.), Canadian Culture, Toronto, Canadian Scholars' Press, 1997, p. 9.
} 
All at once, in the last forty-five years, we have witnessed a real revolution around the world in the relations between states, literatures, ethnocultural minorities and their aesthetic productions. Older models of homogenizing nation-states literatures have been increasingly contested, and often displaced, by newer multicultural models of narratives and interdisciplinary critical approaches. This is reflected, for example, in the écritures migrantes of neo-French-Canadian writers such as Régine Robin, Sergio Kokis, Ying Chen, Kim Thúy, among others - in the widespread adoption of cultural and linguistic interactions, the acceptance of multiple identities and the recognition that stories of survival and resilience can be shared by blending memories of the past - in a native land - withcurrent life in the adopted country. If Will Kymlicka, in Multicultural Odysseys, underlines the importance of the "internationalization' of state-minority relations, and the global diffusion of multiculturalism as a new framework for reforming relations" (2007: 3) - we feel entitled to ask: How do contemporary Canadian writers and artists play with experiences of survival of past experiences without necessarily working to fix them in a victim-hero dichotomy; or in a personal/national vs. transcultural dynamics? How can we think of experiences of survival in relation to multiculturalism, if, in a broad sense, we assume that multiculturalism means "producing cultural heterogeneity" and integrating "geographical and symbolic displacements", according to Patrick Imbert in Multiculturalism in the Americas (2011: 12)?

\section{Survival of the Past and Multiculturalism}

Given these diverse questions, using the term "survival" in relation with multiculturalism risks misunderstanding. From the beginning, it is preferable, for example, to remember that during the $20^{\text {th }}$ century, most often the idea of "survival" has been tied to totalitarian experiences - mainly the Second World War and the Holocaust in Europe [Primo Levi's Survival in Auschwitz (1947) is one of the most compelling accounts of the Holocaust]. This partly justifies the melancholic tropism, which colors the postmodern representations of History and time: History which seems stalled when it does not appear to be focused on catastrophes of the past, in a "pure and simple revisionism of the narrative of emancipation", as stated in The Politics of Aesthetics by Jacques Rancière (2006: 29).

And yet, in spite of the $20^{\text {th }}$-century historical catastrophes in Europe, there are European thinkers who keep the idea of hope alive. The philosopher Walter Benjamin (1999: 247) reflected on the phenomenon of "a messianism without a messiah", while the contemporary art historian Georges Didi- 
Huberman explores "the survival of the fireflies" - La survivance des lucioles - the title of a recent book in which he suggests elevating this fall from grace with individual creativity to new beauty, and turning this decline into a vital resource. For, "closing oneself in the mourning of the archaic can paralyze the survival of the present", writes Didi-Huberman (2009: 32). Admittedly, fireflies are symbolic of the fragility of a future, which is not impossible but it must take into account the imagination, as well as history, life experiences and politics.

But what happens in the New World? How can we speak about the "survival" of past experiences in Canadian literature? How does cultural and historical memory travel from a continent to another, from Europe to the Americas? Nowadays, the lineage between the destruction of European Jews and other violent historical events is constantly underlined since the Holocaust has become: "a template for collective memory in areas of the world that had nothing to do with those events but that have known other collective traumas" (RUBIN SULEIMAN, 2006: 2). In fact, treating the memory of the Holocaust as a paradigm for other traumatic contexts allows us to alleviate the menace of its memory extinction, because seventy years after the Second World War, almost all direct survivors have passed away, and we enter the no witness era.

Thus, this article explores the idea of survival in two contemporary writings on art and the AIDS period of the 1980s, keeping in mind DidiHuberman's questions on what remains of our past. How can we possibly preserve what seems doomed to extinction? Additionally, we aim to discuss the notion of "multiculturalism" in relation to the circulation of memory going beyond its meanings that encompass issues raised by Cultural and Political Studies, Anthropology and History.

In April 2014, the Quebecois writer Catherine Mavrikakis published Diamanda Galas -a tribute to the American artist and performer of Greek origin, Diamanda Galas - at the Montreal Publishing House Héliotrope, inaugurating a new collection, Guerrières et Gorgones (Warriors and Gorgons). At the same time and in the same collection, Martine Delvaux published a tribute to the American photographer of Jewish descent, Nan Goldin, in an eponymous essay. The question of survival is omnipresent in both narratives: "What survives from/through artists who are prophets of the contemporary?”, inquires Mavrikakis (2014: 12). It is eventually the link between art, imagination and politics that illustrates a sense of optimism by breaking away from the doxa of decline, as underlined by Didi-Huberman in La survivance des lucioles:

Our current Unease in culture is apparently headed in that direction, direction in which we are most given to experience it. But it is one thing to identify the 
totalitarian machine and another altogether to grant it such a quick, definitive and absolute victory. [...] It therefore means to not be able to see the spaces of possible opening, of small light, of a spirit of defiance, be them tiny, intermittent, nomadic or in unlikely places. ${ }^{3}$

Such "defiance", such assertion means that the fireflies of art are not dying out, but that the problem might just simply be in the desire of seeing/not seeing. A question can be asked here: can the works of Catherine Mavrikakis and Martine Delvaux on Diamanda Galas and Nan Goldin still lead us to imagine experiences of memory survival positively, beyond such antagonisms as victim and invader, mainstream and marginal, inclusion and exclusion?

Let us point out an obvious observation, namely the lineage between the authors Mavrikakis and Delvaux and the artists Galas and Goldin that they discuss in their tribute narratives. The two writers identify with the artists they are praising in an attempt to eventually rethink the History of contemporary women. Thus, they create portraits of exceptionally singular women that overcome the casualties of destiny through art and creation. Both Galas and Goldin "survive" by building up solidarities with people, and by getting connected to the powerful experiences of loss and trauma that they went though. In Mavrikakis and Delvaux's views, this appropriation is possible through the female body as well as through different self-performances (Diamanda Galas) and photographic scenarios (Nan Goldin). In this fashion, the two artists end up carving a place for themselves in History and breaking the historical repetition of exclusion that most often fatefully pushes women away from the mainstream.

How does multiculturalism and García Canclini’s idea of "imagined globalization" play in this dynamics? In his essay Imagined Globalization, recently published in English (2014), Canclini goes to great lengths to illustrate the importance of cultural products (literature, art, film etc.) and language to imbue meaning and continuity into social relations. In doing so, the author repeatedly rejects the tension between the defense of identity and globalization, but rather asserts that we must learn the benefits of understanding how we can act and be in relation to other groups, engage with heterogeneity, inequality and difference. This conception joins Patrick Imbert's remark that interest for multiculturalism is becoming transcontinental, while "solidarities like new social movements [...] disseminate new perspectives on equality and difference" (IMBERT, 2014: 10).

From a literary point of view, Mavrikakis and Delvaux creatively marshal affinities between artists, multi-faceted fictional scenarios of sharing sto-

${ }^{3}$ Georges Didi-Huberman. La survivance des lucioles, Paris, Minuit, 2009, p. 32. My translation. 
ries and traumatic experiences, questions of hybrid identity and various perceptions on the AIDS period to compel the reader to consider multicultural and global horizons broader than those channelled by linear monolithic historical and life narratives.

\section{The Idea of Survival of the Gorgons}

Both narratives by Catherine Mavrikakis and Martine Delvaux have the subtitle Guerrière et Gorgone that define Diamanda Galas and Nan Goldin as mythological figures. Two portraits - inspiring and sometimes quite personal - that are obviously in dialogue with each other and that remind us of goddesses and saints, and their divine force. 'Les saintes, writes Martine Delvaux, 'sont des femmes que les hommes ne parviennent pas à domestiquer' (2014: 34).

Yet, in spite of the archetype of the "saint", what most connects the two books is the AIDS epidemic of the 1980s and 1990s that profoundly marked the aesthetic productions of Diamanda Galas and Nan Goldin. The exceptional voice of Diamanda Galas incarnates the anger and the pain of mourning, while Nan Goldin develops a photographic art triggered by love for the excluded and marginal. The first artist works to disclose in music what is unfairly intended to silence, while the latter shows through the lens of the camera what people want to hide - that is drugs, alcohol, tormented relationships, dysfunctional families, suicide etc. In their way, the two artists speak in the name of the generation decimated by AIDS.

Catherine Mavrikakis remembers that in 1983:

[...] ceux d'entre nous qui furent épargnés par les foudres aveugles du destin ne firent plus qu'un avec les morts. Nous fûmes Philip Dimitri Galas, frère de Diamanda, mort du sida en 1986, à 32 ans. Nous fûmes Diamanda quand elle se fit tatouer sur les jointures des mains : we are all HIV+. Nous fûmes tous séropositifs. Nous fûmes tous coupables. Ensemble, les défunts et les vivants, nous fûmes rappelés à l'ordre vengeur de la mort, nous fûmes sommés de devenir Antigone. (2014: 59)

Why Antigone today? Hegel compared her to Socrates. Like him, she made the most extraordinary sacrifice for her commitments. They both embody novelty and change. Socrates rejected a school of thinking that saw the task of philosophy to be rhetorical in nature - the Sophistic desire to master the art of argumentation - and embarked instead on a dialectical search for truth. And Antigone? Not only did she attempt the impossible, but she herself seems impossible to label, to define. Who is she, this enigmatic figure? What motivated her to sacrifice her own life to honor her dead brother? And why do we continually return to this figure in our attempts to grapple with the struggles and crises of our own times? 
Like all great Greek tragedies, Antigone presents us with existential questions similar to those addressed by Socrates. In the choral ode to man, human existence is characterized as wondrous, riddle-like, uncanny. Human beings are natural and rational at once, bound by necessity yet gifted with freedom, mortal yet capable of transcending the mere necessities of life and survival, the doers of good and evil, makers and breakers of laws and city walls. Although the story of Antigone addresses these universal and timeless contradictions and perplexities of humankind, it simultaneously tells the story of a singular individual: Antigone, a woman who defies King Creon's edict without any fear, doubts, or regrets. This courageous woman, the fruit of incest, has fascinated philosophers in the nineteenth century, inspired playwrights in the twentieth century, and intrigued feminist thinkers and activists for decades. Across the borders and continents.

In Nan Goldin, Martine Delvaux writes the following in respect to the photographs of the protagonist who integrated the tragedy of a generation to the core of her artcraft:

Si la photographie peut faire parler les gens, elle n'a pas le pouvoir de les empêcher de mourir. Mais Goldin sait aussi que les photos qu'elle prend de ses amis malades réussissent à montrer ce qu'ils sont : des êtres humains, pas des statistiques. (2014: 77)

Nan Goldin had her first exhibition organized by "des gens concernés par le sida" (DELVAUX, 2014: 43) - exhibition widely contested by the Catholic church, and which, on the contrary, ended up attracting crowds of people because of this controversy. Most of us remember that the exhibition was also the occasion for which the now famous red ribbon in the memory of the AIDS victims was created. However, in spite of this visibility, it is clear, that for many readers Diamanda Galas and Nan Goldin are rather unknown artists. Thus, we can consider that Mavrikakis and Delvaux guide us to discover intriguing life paths of contemporary women artists - "warriors and gorgons" who open our eyes and ears on the symbolic heritage of the AIDS period while leading us to question what is left of it today.

All through the two narratives, the analogy between Galas and Goldin and the figure of the Gorgon is essential. It is known that in Greek mythology, the gorgon or the medusa is a female creature whose hair is make of snails and whose look has the power to turn us into stone, to petrify us. Delvaux speaks of the Gorgon in these terms:

On raconte que les Gorgones vivaient près du domaine de la nuit, des Enfers, du royaume des morts. Ce monde, situé là où le soleil disparaît, est le monde du froid et de l'hiver, et le regard pétrifiant de Méduse qu'a voulu anéantir Persée grâce à la force solaire, est celui du gel. Les filles de Méduse sont les gardiennes 
de cet Extrême-Monde qui, à l'image de Méduse elle-même, est un univers de paradoxes, de choses contraires. (2014: 54)

The earliest known record about the myth of Medusa and the Gorgons can be found in Hesiod's Theogony. According to this ancient author, the three sisters, Sthenno, Euryale and Medusa were the children of Phorcys and Ceto, and lived "beyond famed Oceanus at the world's edge hard by Night". ${ }^{4}$ Of the three, only Medusa is said to be mortal, whilst Sthenno and Euryale were immortal. Although Medusa is commonly regarded as a monster, her head is often seen as a protective amulet that would keep evil away. Thus, the image of Medusa's head can be seen in numerous Greek and subsequent Roman artifacts such as shields, breastplates and mosaics. There are also numerous coins that bear not only the imagery of Perseus holding the head of Medusa, but also the head in its own right. Today, figures of Medusa's head belong to the logo of literary and arts magazines (e.g. MuseMedusa. Revue de littérature et d'arts modernes, Montréal, Canada) and fashion companies (e.g. Versace), for example, indicating that the myths of the ancient world are still alive and with us in the contemporary world.

This is to say that Catherine Mavrikakis and Martine Delvaux are not about to deliver insignificant and ordinary narratives about Diamanda Galas and Nan Goldin. Their writings claim the paradoxes of artistic pathways that manage to convert disastrous personal and collective stories into meaningful political and aesthetic statements. Simultaneously, the legitimacy of mythology leads us to further interpret the texts as historical testimonials. Thus, these narratives present a piece of the History of our contemporary world mainly Canada and the United States - and at the same time, they allow us to infer that it is sometimes impossible to understand the History of a country without telling what has been inscribed on the female body; and obviously, what has survived from that part of History in the artistic practices and literary representations.

\section{Survival of the Past into the Present}

It should be clear by now that the two books Diamanda Galas and Nan Goldin are built on analogies and links between the past and the present, the heroines and the Gorgons, the writers themselves and the artists discussed. Furthermore, it is also possible to read the repetition of some of these analogies as an occasion to reveal digressions on the processes of aesthetic creation in relation to the notion of "multiculturalism". Since the importance of

\footnotetext{
4 "The Legend of the Medusa and the Gorgons". URL: http://www.ancient-origins.net/myths-legends-europe/legend-medusa-and-gorgons-002773 (browsed on April 16, 2016).
} 
multiculturalism, as analyzed by Patrick Imbert, lays in its power to "manage dynamic and constructive relationships oriented to a creative and inclusive future" (2011:13),we can argue that Galas and Goldin are capable of transforming tragic, and even grotesque experiences, into "constructive relationships" that lead them to actively master traumatic events and avoid being passive subjects victimized by them.

From this point of view, it is possible to interpret Galas' and Goldin's commitments to creative projects (photography and music) as survival defense mechanisms against violent and aggressive personal and social events that they intend to record. In other words, as techniques of archiving the present in order to preserve the past. While speaking about Nan Goldin's art of photography, Martine Delvaux stresses the idea of "des archives du present":

Tenant la lentille entre elle et le monde, elle a entrepris de produire des archives du présent pour combattre la menace de l'effacement, le trauma de l'oubli forcé comme celui imposé par les parents qui voulaient gommer le suicide de leur première fille. $(2014: 12)$

In Delvaux's text, the obsession with archiving the present through human beings and events can be seen both as a leitmotif and as a preoccupation of Nan Goldin with the question of the survival of the ordinary and the extraordinary of everyday life. Therefore, the aesthetic universe of Nan Goldin is often described as "un pays", a multi-faceted territory, as if to better resonate with the idea of multiplicity and multiculturalism:

Le pays de Nan Goldin, comme celui de la Gorgone, est un pays à la fois ordinaire et extraordinaire. C'est le pays du corps, de la chair. C'est un pays sans checkpoint Charlie, où nous sommes tous des marginaux. C'est le pays du réel. Un pays qui est un bar, un jardin, une chambre, un lit, dont les frontières sont dessinées par la lentille et par le bras qui la tient. Son pays est le lieu d'une expatriée. (2014:56)

These multiple representations of the "pays" lead us to the various paradigms of hybridity specific to the Americas, such as the multicultural nation, the melting-pot, mestizaje, and creolization. As Édouard Glissant pointed out in his influential study of Caribbean discourse, "the Americas have seen the birth of composite societies, instead of atavistic ones as in Europe" (quoted in CHANADY, 2006: 35), which he defines as societies based on filiation, at least in the social imaginary. This concept constitutes a positive paradigm for representing the Americas, not only as an impressive geographical region, but also as an area of rich and heterogeneous cultures where the center-marginal dichotomy is transgressed.

In fact, it is through this solidarity of the marginal, through this condition of an outcast - une expatriée - that Nan Goldin claims the possibility of 
changing traditional perceptions of territory and belonging, of family relations, of homosexuality and the values of the petite bourgeoisie. By symbolically turning her dead sister, Barbara, into a saint, Goldin confirms in a way that through creativity, a woman is able to challenge and overcome her destiny: "Goldin donne à Barbara le visage d'une sainte, gorgone et guerrière, et dans un éternel hommage à sa sœur, refuse d'honorer père et mère, couple hétérosexuel et famille nucléaire, petite bourgeoisie" (2014: 48).

Thus, the past and the present are indeed interlinked: questioning past experiences means questioning present perceptions. Paradoxically, catching the present is a way of not losing the past. At several points in the text, Goldin affirms that photography saved her life.

As for Mavrikakis' narrative, Diamanda Galas is the true incarnation of a cathartic voice and a fierce defender of the theatre of cruelty: "elle fait de la colère [...] un lieu à investir, un actepolitique. [...] L'intolérable Galas me fait entendre la voix de ceux que la vie demande d'oublier"(23). Once more, this figure become the symbol of the fight against oblivion and a prototype of memory transmission. Yet, if Nan Goldin contains the sorrow of the loss of her sister and tends to lock herself in silence, for her part, Diamanda Galas displays art nourished by anger and does not stop voicing her experiences. Galas is a political activist working to keep the memory of the AIDS generation alive. After all, directly or indirectly, both artists are engaged in acts of memory transmission and survival of personal and collective live stories.

\section{Conclusion}

Through the analysis of Nan Goldin and Diamanda Galas from the point of view of memory transmission and a filiation between the artists and the authors who write on them, it is possible to further understand the aesthetic productions of contemporary women in relation to sharing experiences about multiple identities, multiculturalism, as well as transcultural exchanges and questioning of established values. When she speaks about the first encounter with Diamanda Galas, Catherine Mavrikakis remembers:

[...] quand j'ai connu Diamanda Galas, j'ai vu cette possibilité inuïe, presque impensable pour moi, d'être une fille de la Grèce, loin de la terre des ancêtres. Diamanda Galas est née aux États-Unis, à San Diego, en 1955. Cette femme au nom étranger semblable au mien, m’a attirée par une certaine américanité lui permettant de se débarrasser de la Grèce contemporaine. Cette américanité, Galas s'est donné pour tâche de la dénoncer, de la critiquer, mais elle sait quand même en prendre acte. (2014:55-56)

At her turn, Martine Delvaux recognizes her affinities with Nan Goldin too: 
Comme Goldin, je suis une fille du Nord, une fille de l'Amérique froide et métallique, des gratte-ciel immenses et des banlieues miniatures, des choses créées de nulle part et d'autres fabriquées à la chaîne. (2014: 32)

As these quotations show: it is the link between the writers Mavrikakis and Delvaux and the artists Galas and Golding that illustrates how women conquer the territories of their own lives and how they end up conceiving new social constructs of identity in order to reach awareness and extend knowledge about the self, and the place of the self in the world.

Let us remember that in Imaginary Bodies: Ethics, Power and Corporeality, Moira Gatens underlines that many feminist thinkers present women as occupied territories and men as invaders. Thus, in Mavrikakis and Delvaux's narratives, the symbolic appropriation of stories from the AIDS generation is essential because it allows Galas and Golding to decisively get rid of those who desire their failure, while gaining a life of their own. From this perspective, the two artists are prototypes of survival as well as of memory transmission.

The tributes to Diamanda Galas and Nan Goldin by Catherine Mavrikakis and Martine Delvaux establish a filiation that breaks up the grim destiny of women that have in common the loss and traumas of the AIDS generation. This filiation is made possible through self-performances and photography. When the AIDS period turns into a creative process, it is genuinely possible to imagine a legendary universe where women survive in a primordial sisterhood sustained by a sense of presence and connection with mythological figures. For Mavrikakis and Delvaux, mythology is a pathway to rethink contemporary History in a transcultural framework. In their texts, the female characters successfully play the appropriation of individual and collective narratives, and consequently, they inscribe themselves in History. And History becomes then a metaphor of survival

Finally, we can affirm that if in 2010, Canadian Literature journal stated the platitude of Canadian literature - four years later, in 2014, the tribute narratives by Catherine Mavrikakis and Martine Delvaux prove the compelling diversity of contemporary French-Canadian literature.

\section{Bibliography}

---. "The Legend of the Medusa and the Gorgons". URL: http://www.ancient-origins. net/myths-legends-europe/legend-medusa-and-gorgons-002773 (browsed on April 16, 2016).

ATWOOD, Margaret. Survival: A Thematic Guide to Canadian Literature. Toronto: McClelland \& Stewart, 2004.

BENJAMIN, Walter. "Thesis on the Philosophy of History". In: Illuminations, translated by Harry Zohn. London: Pimlico, 1999. 
CAMERON, Elspeth (ed.). Canadian Culture. Toronto: Canadian Scholars' Press, 1997.

CANCLINI, Néstor García. Imagined Globalization, translated by George Yúndice. Durham and London: Duke University Press, 2014.

CHANADY, Amaryll. "Inter-American Reflections on Community”. In: Chanady, A., Handley, G. \&Imbert, P. (ed.), Americas' Worlds and the World's Americas. Ottawa: Legas, 2006: 34-43.

DELVAUX, Martine. Nan Goldin. Montréal : Héliotrope, 2014.

FEE, Margery. "Beyond Boomer Nationalism”, CanLit, no. 206, autumn 2010: 6-11. URL: https://canlit.ca/article/beyond-boomer-nationalism/ (browsed on April 12, 2016).

GATENS, Moira. Imaginary Bodies: Ethics, Power and Corporeality. London and New York: Routledge, 1996.

DIDI-HUBERMAN, Georges. Survivance des lucioles. Paris : Minuit, 2009.

IMBERT, Patrick. Comparer le Canada et les Amériques. Des racines aux réseaux transculturels. Québec : Presses de l'Université Laval, 2014.

IMBERT, Patrick (ed.). Multicultural Interactions. Canada and the World. Ottawa: Chair: "Canada: Social and Cultural Challenges in a Knowledge- Based Society" Publisher, 2014.

IMBERT, Patrick (ed.). Multiculturalism in the Americas: Canada and the Americas. Ottawa: Chair: "Canada: Social and Cultural Challenges in a KnowledgeBased Society” Publisher, 2011.

KYMLICKA, Will. Multicultural Odysseys. Navigating the New International Politics of Diversity. Oxford: Oxford University Press, 2009.

LEVI, Primo. Survival in Auschwitz and the Reawakening: Two Memoirs, translated by Stuart Woolf. New York: Summit Books, 1986.

MAVRIKAKIS, Catherine. Diamanda Galas. Montréal : Héliotrope, 2014.

RANCIÈRE, Jacques. The Politics of Aesthetics. London/New York: Continuum, 2006.

RUBIN SULEIMAN, Susan. Crisis of Memory and the Second World War. Cambridge and London: Harvard University Press, 2006.

Adina Balint é Professora de Estudos franceses na Universidade de Winnipeg (Canadá). Doutorado pela Universidade de Toronto. Os principais temas de suas pesquisas são: literaturas moderna e contemporânea, com ênfase para a poética da criação e o multiculturalismo. Atualmente trabalha sobre as relaçóes entre a literatura e as artes visuais em contextos transculturais.

E-mail: a.balint@uwinnipeg.ca 